\title{
TTR
}

Traduction, terminologie, re?daction

\section{On Translating Pidgins and Creoles in African Literature}

\section{Paul F. Bandia}

Volume 7, numéro 2, 2e semestre 1994

Traduire les sociolectes

URI : https://id.erudit.org/iderudit/037182ar

DOI : https://doi.org/10.7202/037182ar

Aller au sommaire du numéro

Éditeur(s)

Association canadienne de traductologie

ISSN

0835-8443 (imprimé)

1708-2188 (numérique)

Découvrir la revue

Citer cet article

Bandia, P. F. (1994). On Translating Pidgins and Creoles in African Literature. TTR, 7(2), 93-114. https://doi.org/10.7202/037182ar

\section{Résumé de l'article}

De la traduction des pidgins et des créoles dans la littérature africaine - Cet article présente certains problèmes posés par la traduction des pidgins et des créoles dans la littérature africaine. L'introduction est un bref survol des origines et de l'évolution parallèle des pidgins à base lexicale anglaise et française parlés en Afrique de l'ouest, leur statut, leur histoire et leur usage dans la littérature africaine. Après un tour d'horizon des aspects sociolinguistiques de ces langues hybrides, l'auteur procède à une analyse des difficultés que pose leur traduction, et effectue une analyse approfondie de quelques traductions. Des versions plus adéquates sont proposées au besoin. En conclusion, sont mises en évidence les raisons de ces difficultés de nature non seulement linguistique mais historique et idéologique.
Tous droits réservés @ TTR: traduction, terminologie, rédaction — Les auteurs, 1994
Ce document est protégé par la loi sur le droit d'auteur. L’utilisation des services d'Érudit (y compris la reproduction) est assujettie à sa politique d'utilisation que vous pouvez consulter en ligne.

https://apropos.erudit.org/fr/usagers/politique-dutilisation/ 


\section{On Translating Pidgins and Creoles in African Literature}

\section{Paul F. Bandia}

\section{Introduction}

A great number of West African authors have used pidgins and creoles (PCs) in their works, usually in an attempt to assign the proper linguistic code to characters who represent the earliest contacts between Europeans and Africans, or who simply represent the uneducated or semi-literate segments of the population of a more modern Africa. As far as creative writing in English is concerned, the writers have endeavoured to capture the narrative devices of African oral tradition and languages in their novels, but they also had the task of appropriately employing the varieties of English or English-based "languages" spoken by West Africans. There are Pidgin Englishes, creoles, the English of secondary school leavers, the English of university graduates, officialese, etc. (Chinweizu et al., 1980). A similar phenomenon occurs among French-speaking writers of West Africa. In fact, for many of these writers this is a sure way of capturing the sociolinguistic and sociocultural realities of African life in the African novel. Our aim, in this paper, is to acquaint the reader with the use of these language varieties and to discuss the problems they pose for translators of African literature. 


\section{English-based pidgin}

West African Pidgin English (WAPE, henceforth) ${ }^{1}$ is the result of a combination of several African languages and some European languages (English, French, Portuguese, German, etc.) (see Todd 1982, 1984; Schneider, 1966). The grammar, and particularly the syntax, of this "language" is influenced, to some extent, by the grammar of the African languages with which the European languages have come in contact. Aspects of African oral tradition can also be found in pidgin. Indeed, one might say that such pidgins are a classic case of what can happen when two or more mutually alien languages and cultures are in contact. The use of pidgin spread fairly rapidly among Africans, particularly because of the numerous peculiarities of the indigenous languages and cultures it had absorbed. For a long time pidgin has thrived as the contact language used by the uneducated or semi-literate urban dwellers from various ethnic backgrounds. Most of these urban dwellers were from the working-class and often characterized by their low level of formal education and low economic and social status (Obiechina, 1975). However, today pidgin is used by Africans of all social and economic backgrounds. Well-educated West Africans use pidgin in their verbal interaction with uneducated West Africans from different ethnic groups, and also to talk among themselves in certain informal contexts. In fact, West Africans of all backgrounds use pidgin as a means to ensure group solidarity, and to reinforce a sense of integration, the use of language Malinowski refers to as "phatic communion'." Furthermore, one might say that pidgin flourished not only because the traditional African initially found it difficult to communicate fluently in European languages, but also because given the nature of pidgin ( $a$ blend of African and European

1. In this paper, we are interested in the pidgin English spoken in some West African countries such as Cameroon, Nigeria, Ghana, Sierra Leone.

2. See C. K. Ogden and I. A. Richards (The Meaning of Meaning, 1923), p. 315. 
languages), most Africans found it to be a better medium than European languages for expressing certain ideas and concepts of African sociocultural reality.

In Achebe's $A$ man of the people (1966), an urban novel, there is an abundant use of pidgin by characters who have refined their pidgin to a point where they can come up with idiomatic expressions fashioned after such expressions in the oral tradition. For example, when a character expresses disgust at the suggestion that the more modern Cambridge Certificate is as good as the Standard Six Certificate they obtained in their days, he says: "Who dash frog coat" (p. 11) (i.e. "You must be kidding."). Elsewhere in the novel one character says of another: "E fool pass garri" (p. 56) (i.e. "He is very foolish"). Another character exclaims in disbelief: "True, give me tori" (p. 20) (i.e. "Oh really, tell me about it"). These pidgin statements are striking in that, although some English words are used, they are clearly patterned after similar types of discourse in the African oral narrative. "Who dash frog coat," for instance, is a replica of what happens in traditional African folktales, namely, the assignment of human traits to animal characters. This often creates humour, which in this case can be seen in the laughable idea of a frog wearing a coat. The statement refers to someone acting above his station. In the early days when Africans became increasingly interested in Western education, wearing a coat was considered prestigious and was generally identified with the intellectual elite. In the pidgin statement, the speaker is making fun of a situation by likening it to a frog owning a coat. A similar comment would apply to the statement "E fool pass garri." In this

3. "Dash" means giving something away for free. Translated literally the statement means, "Who gave away a coat to a frog?"

4. A literal translation of the statement is something like: "He is more foolish than garri." "Garri" is an African dish made with cassava (manioc) flour. When the flour is steeped in water, it rises (i.e, it becomes "full"); hence the play on the words "full" (as in "garri full," meaning "garri has been soaked in water"), and "fool" (as in being "foolish"). 
case an individual is ridiculed by being compared to a popular dish. "True, give me tori" is reminiscent of the manner in which people show excitement about gossip in some oral tradition contexts. Pidgin words may also be used for lack of an English equivalent, or simply for local colour. For example, in Things Fall Apart, Achebe uses the term inyanga for local colour and for lack of an English equivalent which can capture the various shades of meaning implied by the use of the term. In the statement, "Ezinma had been making inyanga with her pot," the word means "showing off." Of course, this is a somewhat loose translation. The term is used here to reflect the kind of "showing off" that little boys and girls sometimes indulge in to defy parental authority. Indeed, it conveys the silliness in Ezinma's action as she broke a clay pot by trying to balance it on her head to impress her friends.

\subsection{Status of West African Pidgin English}

The linguistic status of WAPE is still greatly debated. On the one hand, there are those who, perhaps for political and ideological reasons, would like to dismiss it as the result of inadequate knowledge of the English language. And, on the other hand, there are scholars who, after careful research, consider WAPE a language like any other. For instance, Gilman (1979) points to the relative autonomy of Pidgin when he says:

Pidgin [...] is different from English and used for different purposes, so that people who know English quite well continue to use Pidgin for some purposes, and English for others. It is this ability of speakers to keep the two languages separate and use them for different purposes, which distinguishes Pidgin from imperfectly learned English. (p. 272)

Pidgin has evolved, over the years, from a language of communication between the native African and the white man into a lingua franca for the people of West Africa. This evolution has also meant that as more and more Africans have become educated, a wide variety of pidgins has developed, ranging from the pidgin spoken by Achebe's illiterate characters of the colonial era to the 
pidgin spoken today by the well-educated African. The existence of this kind of pidgin continuum has been discussed by, among others, Bickerton (1975) who talks of a "dynamic system" within which there are variants ranging from a "basilect" (the variety furthest from English) through the "mesolect" (variety spoken by semi-literate people) to the "acrolect" (standard West African English). According to Bickerton's continuum, the variety of pidgin one speaks is in relation to how much English one knows. Based on this fact, pidgin does not constitute a language in so far as one end of the continuum is indistinguishable from English (p. 166). Todd (1982), however, describes WAPE as an "expanded pidgin" as opposed to a "restricted pidgin" in an attempt to assign it an independent status. Three reasons point to the fact that WAPE can be considered an independent "language" and not just a "basilect" variety of the English language. Firstly, there are several speakers of pidgin in West Africa who do not speak or understand English, and for this group of people pidgin is another language with a somewhat similar status to their vernacular, except that it has an additional advantage - it is spoken by people of different ethnic backgrounds. Secondly, pidgin has become the mother-tongue of most children born to parents from different ethnic backgrounds. Thirdly, according to Mufwene (1988b), the study of the grammar of pidgin is not particularly different from the study of the grammar of other languages. We infer from this that WAPE, from a grammatical point of view, also has the main characteristics of a language.

Holm also argues in favour of the autonomous "language" status of pidgin when he states that:

If one examines them as linguistic systems [...] it becomes evident that these systems (pidgins and creoles) are quite different from those of the language from which they drew their lexicon [...]. Their lexical source or base language [are] so different, in fact, that they can hardly be considered as even dialects of their base language. (Our emphasis) (1988, p. 1)

5. Indeed, some scholars consider WAPE to be a creole (see Mufwene, 1988a, for arguments). 
In the Dictionnaire encyclopédique des sciences du langage, by Ducrot and Todorov (1972, p. 82), pidgins are described in these terms:

On parle [...] de langue pidgin lorsqu'il y a eu création d'une langue grammaticalement cohérente et qui, d'autre part, répond au même titre que les langues nationales et dialectales, à l'ensemble des besoins de communication de ses utilisateurs (avec la possibilité de devenir le support d'une littérature). Lorsque cette langue devient la langue principale (ou unique) d'une communauté, on parle de langue créole.

We are therefore inclined to consider WAPE as a "language" in its own right. Unlike Bickerton, instead of appending pidgin at the lowest end of the English language continuum, we suggest that pidgin should have a continuum of its own, quite distinct from that of the English language in West Africa.

It is necessary to make this distinction between pidgin and the English language in West Africa in order to have a clear understanding of the nature and use of pidgin in the works of African writers. It is important to realize that WAPE is not what has been derogatorily referred to as "broken English"," and that it is not in a diglossic relationship (Ferguson 1959, p. 325) with standard West African English.

The back and forth movement between the European language of writing and pidgin which takes place in the West African novel can therefore be adequately described as codeswitching between two relatively autonomous languages, and not as a situation in which there is a rise and fall in the standards (or levels) of one and the same language.

6. "He looked round slowly, sank into utter despair and even turned to broken English, 'Look how we sleep like munmu. We no even sabbe wetin that bastard done leave behind'." (Soyinka, Aké, 1981 , p. 191). It is rather ironic that one of Africa's best writers, Wole Soyinka, would refer to WAPE as "broken English." 


\section{French-based pidgin}

Some French-speaking African writers have also sought to represent the various sociolinguistic groups that make up the fabric of West African society in their novels, by depicting the varieties of French used. Ferdinand Oyono, in Une vie de boy, for instance, has tried to reproduce the variety of French his illiterate or village characters would use in interacting verbally with their European bosses. However, the French-speaking writers have not always been as successful as their English-speaking counterparts in reproducing the "language" of semi-literate Africans in their works for several reasons. Although today some scholars point to some form of "pidgin French" in some West African countries, it can safely be said that a pidgin has not evolved from the French language in West Africa to the same degree as it has from English? ${ }^{7}$. Some of the reasons can be found in the differences between the British and French colonial policies in Africa, whereby, through the French policy of Assimilation, French-speaking West Africans strove to

7. The following are some five varieties of popular French spoken in African urban centres:

- Français de Moussa, Français de Treichville, or Petit français (considered a form of creole) spoken in Côte d'Ivoire and highly influenced by Dioula-Taboussi, the most popular local language (see Brigitte Tallon, "Le français de Moussa," Autrement, horssérie 9, "Capitales de la couleur," octobre 1984, pp. 148-157);

- Camfranglais, a mixture of French, English and the national languages, spoken in Cameroon (see Michel Lobé Ewané, "Le Camfranglais, un cousin du Verlan," Afrique Élite, 36, avril 1989); - the variety spoken in Zaire which is highly influenced by Lingala, a widely spoken local language, as well as remnants of belgicismes left over from the colonial era;

- the variety spoken in Rwanda heavily influenced by Swahili and a local language (kinyarwanda) and also belgicismes and, more recently, canadianismes inherited from Canadian coopérants.

- the variety spoken in Senegal which is heavily influenced by Wolof, the main national language (for more information, see Inventaire des particularités lexicales du français en Afrique noire, $2^{\mathrm{e}}$ édition, Paris, EDICEF/AUPEAF, 1988). 
speak like Frenchmen, whereas in English-speaking West Africa, the policy of Indirect Rule instituted by the British gave Englishspeaking Africans the relative freedom to experiment with the English language ${ }^{8}$.

\subsection{Status of French-based pidgin}

In most French-speaking West African countries there is "discontinuité interlinguistique" (Wald, 1973, p. 123) between the French language and any emerging form of "pidgin French." In his study of the sociolinguistic situation of the French language in West Africa, Wald proposes two possible scenarios:

(a) French as an official language exists side by side with the lingua franca (langue véhiculaire) of the community;

(b) French is both the official language and the lingua franca (langue véhiculaire) of the community (in the absence of an African - indigenous - lingua franca).

Given scenario (a), there is "discontinuité interlinguistique," that is, French is reserved for the educated elite and will thus remain standard with little or no chance of becoming pidginized. In the (b) scenario, on the contrary, French tends to get closer and closer to the African vernaculars and at some point it is difficult to know exactly where the people draw a line between speaking a Frenchbased pidgin and the French language proper.

In these countries, there seems to be a situation whereby standard French exists side-by-side with the African vernaculars, but where there is a variety of French spoken by mostly the uneducated mass of the people. This variety of French does not fit the definition of a "pidgin" for several reasons. First, unlike Pidgin English, the variety is spoken almost exclusively by the illiterate population, since educated francophones would rather speak standard French; secondly, the grammar and structure of the variety is highly idiolectal and idiosyncratic, since it is very likely that the village

8. See Todd (1982); Gérard (1986). 
farmer will not use the same grammar and structure as his blacksmith neighbour; and thirdly, it is used in very limited circumstances, such as verbal communication between illiterates from different ethnic groups, or between an educated francophone and a non-educated interlocutor ${ }^{9}$. Another significant difference between Pidgin English and this variety of French is that speakers of the former are not often trying to speak standard English ${ }^{10}$, while speakers of the latter, for the most part, think they are speaking standard French. This variety of French has been derogatorily referred to as "français petit-nègre" (Alexandre, 1972, p. 59), or "broken French." Furthermore, the use of Pidgin English in a West African novel written in English does not automatically convey any sociolinguistic information about the speaker as it would for a speaker of "français petit-nègre" in a West African novel in French.

\section{Translating hybrid languages}

The pidgins and creoles found in the works of some West African authors pose specific translation problems. Besides assigning to the characters the appropriate language suitable to their position in precolonial, colonial or post-colonial society, the use of pidgin enhances the Africanness of the novel and deals with the setting in a more realistic fashion. It is important for the translator to retain those aspects of the African novel that account for its Africanness.

In discussing what he refers to as "réseaux langagiers vernaculaires," Antoine Berman (1985) makes very valid points that can also throw light on the translation of pidgins and creoles in West African literature. In his view:

9. In this situation the variety is used only by the non-educated speaker.

10. Speakers of Pidgin English make a clear distinction between the two, calling standard English "Gramma" (grammar). 
[...] toute grande prose entretient des rapports étroits avec les langues vernaculaires. "Que le gascon y aille, si le français n'y peut aller!", disait Montaigne.

En premier lieu, la visée polylingue de la prose inclut forcément une pluralité d'éléments vernaculaires.

En second lieu, la visée de concrétude de la prose inclut nécessairement ces éléments, car la langue vernaculaire est par essence plus corporelle, plus iconique que la koinè, la langue cultivée. Le picard "bibloteux" est plus parlant que le français "livresque". Le vieux français "sorcelage" plus riche que "sorcellerie", l'antillais "dérespecter" plus direct que notre "manquer de respect".

En troisième lieu, la prose peut se donner comme but explicite la reprise de l'oralité vernaculaire [...].

L'effacement des vernaculaires est donc une grave atteinte à la textualité des œuvres en prose. (1985, pp. 78-79)

It is therefore important to retain the "langage vernaculaire" in the process of translation, in much the same way as it is important to represent the social fabric of African society through the various "sociolects" of the characters in a novel. As Berman (1985) puts it:

La prose littéraire se caractérise en premier lieu par le fait qu'elle capte, condense et entremêle tout l'espace polylangagier d'une communauté. Elle mobilise et active la totalité des "langues" coexistant dans une langue. [...] au point de vue de la forme, ce cosmos langagier qu'est la prose, et au premier chef le roman, se caractérise par une certaine informité, qui résulte de l'énorme brassage des langues opéré dans l'œuvre. (p. 66)

Nida also discusses the significance of maintaining and translating dialect forms in a text when he says:

More frequently the dialect forms used by writers are either horizontal (geographical) or vertical (socioeconomic) dialects, and rarely do authors or translators consistently represent all the details of such dialects, but at least certain easily recognized features are selected that serve to signal the type of dialect being used. A form such as 'you all' is supposed to typify Southern American English, and boid 'bird' and goil 'girl' are supposed to represent the Lower 
east Side of New York City. The problem for the translator is to find in a foreign language a dialect with approximately the same status and connotations. Rarely is the dialect match fully successful, for the values associated with a particular dialect are often highly specific. $(1976$, p. 55)

In discussing the concept of equivalence, Catford (1965, p. 112) also alludes to the varieties of "language" that can be found in a novel. He mentions the idiolect, which helps to identify a character in a novel, dialectal variants, e.g., geo-social ones, such as the translation of a passage from Cockney in the South-east of England into Parisian, and the various language levels (popular, familiar, colloquial, etc.).

The ideas set forth by these scholars show how important it is to represent society in a novel fully by including the various sociolinguistic backgrounds of the characters, and, above all, they point to the difficulty and the necessity of translating what Berman calls "les réseaux langagiers vernaculaires" $(1985$, p. 78 ) found in certain novels. These dialect forms are often charged with meaning and can reveal a great deal of sociocultural information about the people or society concerned in the novel.

\subsection{The Case of West African Pidgins and Creoles}

The difficulty in translating pidgins and creoles in the African novel lies in the fact that there is hardly any direct equivalent relationship between English-based pidgins and French-based pidgins in West Africa. Some light has been thrown on the different status of these two types of pidgin in the previous pages. Passages in pidgin in a West African novel in English are easily recognizeable and comprehensible as they are written in a "language" that is identifiable as WAPE. One cannot say the same for passages of French-based pidgins as they do not reflect, or emanate from, an established form of pidgin, but rather represent a sort of "broken" French which varies from one author to another, as it varies from one speaker to another in real-life usage. In fact, a French-based pidgin passage is solely the creation of the Francophone writer who 
tries to imagine the kind of "broken" French spoken by the illiterate and semi-literate characters of his novel, whereas an English-based pidgin passage will generally have parallel forms within the PidginEnglish communities in West Africa. In other words, the Englishbased passage is often reflective of the pidgin spoken in real life whereas the French-based pidgin is not. Some scholars point to the fact that the linguistic elements of WAPE are also not stable, varying from one writer to another. These scholars may not be making the distinction between orthographical conventions and grammar. It has been shown clearly that the grammar (syntax, morphology, morpho-phonology, etc.) of WAPE is fairly stable with occasional variants such as can be found in any other language.

Since the orthography and "grammar" of French-based pidgin passages vary from one author to another, the reader of African French-language novels often relies on his own intuition to pick through the "mess" (so to speak) created by the author's deliberate "de-grammatization" of the French language in order to figure out what the character (or speaker) is saying. The following comment shows how difficult it was for Ferdinand Oyono to define this variety of French:

Les élèves chantèrent d'une seule traite dans une langue qui n'était ni le français ni la leur. C'était un étrange baragouin que les villageois prenaient pour du français et les Français pour la langue indigène. $(1956, \mathrm{p} .63)^{11}$

In fact, the impression created by a French-based pidgin passage is that the speaker has a poor knowledge of the French language, whereas any reader familiar with the English-based pidgin will recognize such a passage as belonging to a well-established lingua franca in West Africa.

11. See section on Translating French-based Pidgins for examples. 


\subsubsection{Translating English-based pidgin}

A close look at the following English-based pidgin passage and its translation into a so-called French-based pidgin will illustrate our point.

I use to tellam say blackmanjuju no be someting wey man fit take play. But when I tellam na so so laugh im de laugh. When he finish laugh he call me John and I say Massa. He say You talk bush talk. I tellam say O-o, one day go be one day. You no see now $?^{12}$ (Achebe, Arrow of God, p. 155)

Translation:

Moi dire lui que gri-gri de l'homme noir être quelque chose avec quoi personne y doit jouer. Mais quand moi dire lui, lui rire, rire seulement. Quand lui fini rire, lui dit "John" et moi répond "Missé", y dit moi aussi parler comme broussard. Moi dis lui!! "O-o, un jour va vini [...] et on va voir. Ti voi maintnant? (d'Almeida et al., 1978, p. 206)

Apart from the "unnaturalness" of this kind of mimicry of Pidgin English, what is also striking is the apparent lack of identity of the French version due to a significant loss of those aspects of African oral tradition which constitute a basis for the ethnolinguistic characteristics of the passage in WAPE. In other words, there is hardly anything typically West African in the French-based passage, whereas the English-based passage is clearly identifiable as a

12. A translation of the pidgin passage into standard English:

I used to tell him that nobody fools around with black magic. But each time I said so he would simply laugh it off. When he finished laughing he would call out my name "John" and I would answer "Sir." He would say, "You are talking like a 'savage." Then I would say to him, "Well, some day you will have first-hand experience of $i t$, and then you will believe me." And that day has come. 
Nigerian variety of $\mathrm{WAPE}^{13}$. Indeed, the French-based passage could also be attributed to an illiterate speaker of French in many former French colonies outside Africa, particularly those within the black diaspora. It might seem plausible that WAPE could be translated into French-based creoles spoken in the Caribbean which are quite stable and have a comparable linguistic status. However, such a solution is likely to open up a Pandora's box of linguistic, historical, political and ideological concerns.

One of the elements of African oral narrative lost in the translation is the repetition in "na so so laugh im de laugh." "So so" is recognizeable as a grammatical unit in Pidgin English, used often for emphasis, recurrence, or duration (see Todd, 1982; 1984). The French version "lui rire, rire seulement," though a repetition, does not reflect the grammatical importance of the expression "so so" in Pidgin English. Another aspect of the African oral narrative lost in the translation is the pidgin proverbial saying (fashioned after the African proverb) "One day go be one day." Paraphrasing it into English without the loss of its oral narrative quality is extremely difficult. Our translation of this into standard English in the footnote ("And that day has come") does not carry the same weight as the original. Its translation into French as "un jour va vini [...] et on va voir" is inadequate as the translation cannot be recognized as a proverbial saying, with all the attributes of wisdom, knowledgeability and succinctness usually implied. Hence, due to the loss of the ethnocultural qualities borrowed from African oral tradition, the translation is not easily recognizeable as West African and consequently does not enjoy the same status as the original passage in WAPE.

Here is another example from Arrow of God and its translation. In the early West African novels (i.e., those dealing with colonial times), pidgin was mainly used as a means of communication between native Africans and white settlers. These

13. As opposed to a Cameroonian, Ghanaian or Sierra Leonese variety. 
native Africans, who often worked for the settlers, seemed to have formed a class of their own and, believing that they were actually speaking the white man's tongue fluently, began to feel superior to their fellow native Africans who did not speak any pidgin. The following passage shows how two African policemen working for the colonial administration would speak to their countrymen in the local vernacular, but would confer with each other in Pidgin English, as if it had become a private code for a new class of Africans.

'The two policemen conferred in the white man's tongue to the great admiration of the villagers. "Sometine na dat two porson we cross for road" said the Corporal. "Sometine na dem" said his companion. "But we no go return back jus like dat. All dis waka wey we waka come here no fit go for nating". The Corporal thought about it. The other continued - "Sometine na lie dem de lie. I no wan make dem put trouble for we head. ${ }^{14}$ (pp. 153-154)

\section{Translation:}

Les deux policiers se consultèrent dans la langue de l'homme blanc, à la grande admiration des villageois. - C'est pê-ête les deux hommes-là nous rencontrer sur la route, dit le caporal.

- Pê-ête c'est eux, répondit son compagnon. Mais nous pas retourner comme ça. Tout cette marche nous marcher! Ça peut pas ête pour rien. Le caporal réfléchit. L'autre continua.

- Pê-ête eux mentir. Moi veux pas eux mête palabre sur nos têtes. (d'Almeida et al., 1978, pp. 204-205)

14. A translation of the pidgin passage into standard English:

The two policemen conferred in the white man's tongue to the great admiration of the villagers.

"Maybe it's the two men we passed on our way here," said the Corporal.

"Maybe it's them," his companion replied. "But we can't go back empty-handed. All the trekking we did to get here cannot go for nothing." The Corporal thought about it. The other continued "Maybe they are lying to us. I don't want them to get us into trouble." 
The translators have made quite a commendable effort to render the meaning of the above pidgin passage. Although it is mainly "broken" French, it will generally require just a little effort on the part of an informed reader to grasp the message of the dialogue. In fact, it is far more comprehensible than Pidgin English. Indeed, this latter point bears testimony to the relative autonomy, or independent status, of WAPE. However, one has the feeling that there is something missing in the translation; something we will refer to as the "Africanness" of the dialogue. For instance, in the statement, "All dis waka wey we waka come here no fit go for nating," the expression "no fit go for nating" is a well-known one often used by corrupt officials and local law enforcement officers when they are about to extort money from an individual not found guilty of a purported offence. Usually these corrupt officials push their victims to the limit until they find a reason to extort a bribe from them, for as the saying goes, "nating no fit go for nating" (i.e. Nothing goes for nothing). The translation "Tout cette marche nous marcher! Ça peut pas ête pour rien" is at best a reproduction of the meaning implied in the original statement, but it clearly does not have the same impact in the French text as the fixed expression does in the English text. A more adequate translation can be achieved here only through a careful rendering of both the content and the form of the expression, which are seriously grounded in the sociocultural world-view of traditional African society. In other words, a French-speaking African will not react in the same way towards the translation as the English-speaking African would towards the original ${ }^{15}$.

\subsubsection{Translating French-based pidgin}

It is also worthwhile to study what happens when so-called Frenchbased pidgins (i.e. "broken" French), which are much less codified, are translated into the more codified English-based pidgins of West Africa. One would expect the process to be much easier, as the

15. See d'Almeida (1980) for comments based on first-hand experience with translating WAPE in Achebe's Arrow of God. 
translation is carried out from a much less standardized form of pidgin into a more recognizeable variety of pidgin. The following are examples of this kind of translation taken from Oyono's Une Vie de Boy (1956) and their translations:

(1) "Monz'ami, [...] nous pas buveurs indigènes!" (p. 77)

"Man [...] We no be native drinkers" (Reed, 1966, p. 49)

(2) "Petit Joseph pati rôti en enfer" (p. 34)

"Small Joseph go burn in hell" (Reed, 1966, p. 22)

(3) "Y en a vérité, Sep (Chef)" (p. 39)

"It is truth, sah" (Reed, 1966, p. 25)

(4) "Movié (mon vieux! en petit nègre)! [...] Zeuil-de-Panthère cogner comme Gosier-d'Oiseau! Lui donner moi coup de pied qui en a fait comme soufat'soud' [...] Zeuil y en a pas rire $[\ldots]^{\prime \prime}$ (p. 40)

"Man [...] Panther-Eye beat like Gullet. Him kick me bam! Go like dynamite. Panther-Eye no joke." (Reed, 1966, p. 25)

Reed's translation of these pidgin sequences reveals the fact that, as a non-native speaker of WAPE, he relied heavily on the principle of rendering what has been referred to as "broken French" by "broken English." He followed the French text very closely in order to come up with what he imagines should be the kind of English spoken by such characters in the novel. Yet, it would have been more appropriate for him to seek the help of native speakers of WAPE, which would have led to a translation that is more representative of the kind of pidgin spoken by such characters in the West African setting. One might argue against translating "broken French" into WAPE as both language varieties evolved under different historical, political and ideological circumstances. However, this reasoning raises other questions. Does the writer use "broken French" to convey a politically and ideologically charged message or is he simply trying to represent a certain social class by expressing their sociolinguistic habits? Should the translator put more effort into trying to acquaint his English readership with the linguistic characteristics of "broken French," or should he simply 
provide his readers with a known English-based equivalent of this variety of French spoken by a certain social class? In our opinion, it seems more reasonable to use an English-based equivalent readers can easily recognize, and yet succeed in representing a comparable social class in the English-speaking community.

The translation of (1) as "Man [...] We no be native drinkers" and (2) as "Small Joseph go burn in hell" reminds one of the kind of approximate pidgin spoken by European missionaries in Africa. A native-speaker of WAPE would say something like: (1) "Massa, [...] We no de drink mimbo like bush people," the noun phrase "native drinkers" being a little too recherché for the illiterate speaker of pidgin; (2) "Small Joseph $i$ go burn for hellfire." "Go burn in hell" is also closer to the kind of "standard" English that is not within the reach of the illiterate speaker of pidgin. Also, a native-speaker of WAPE will translate " $Y$ en a verité, Sep" as "na true, sah" and not "It's truth, sah" as translated by Reed. "Na," of course, is the recognized grammatical equivalent of "It' $s$ " in WAPE (see Todd, 1982; 1984). Also, the noun "truth" does not exist in this variety of pidgin.

The translation of passage (4) is a clear indication that Reed merely sought to replace what is obviously "broken French" with "broken English" (as opposed to Pidgin English), without regard for the fact that there is a well-established form of Pidgin English in West Africa. For a WAPE speaker the translation would normally read something like the following: "Massa [...] Panther-Eye $i$ de beat like Gullet. $i$ kick me bam! $i$ be like thunder. Panther-Eye no de joke." Apart from using the wrong pidgin grammar, Reed uses a word like "dynamite" which is not available to the illiterate speaker of pidgin.

Indeed, our suggested translations are more representative of the kind of pidgin spoken by these West African characters. Reed's renditions hardly represent the speech of any linguistic community in that part of the world, except for the community of Western missionaries and businessmen who occasionally attempt to carry on a conversation in pidgin with illiterate indigenous people. 


\section{Conclusion}

Thus, besides compensating for the lack of European-language equivalents, pidgins and creoles are used in the works of African writers for local colour, to reflect the sociolinguistic background of West African society, and to illustrate the extent to which African oral tradition has reshaped the European languages spoken in this part of the world.

Indeed, the translation of pidgins and creoles is not an easy exercise. D'Almeida likens it to the difficulty of translating dialects from a specific source language into a target language, such as translating a dialogue written in Scottish English into French (1980, p. 28). Unlike the anglophone writer who often has a good command of the English-based pidgin (since WAPE is fairly stable), the francophone writer often has to deal with a hybrid language ("broken French") whose linguistic characteristics are ill-defined for reasons outlined at the beginning of this paper. This difference in status between WAPE and "broken French," coupled with the difference in linguistic attitudes towards the two hybrid languages, accounts for a great deal of the difficulties encountered by translators of African literature.

Concordia University

\section{References}

ACHEBE, C. (1958). Things Fall Apart. London, Heinemann.

(1964). Arrow of God. London, Heinemann.

(1978). La flèche de Dieu. Trans. by I. A. d'Almeida and O. M. L. Simpson. Paris, Présence Africaine.

(1966). A Man of the People. London, Heinemann. 
ALEXANDRE, P. (1972). Languages and Language in Black Africa. Trans. by F. A. Leary. Evanston, Northwestern University Press.

BERMAN, A. (1985). Les Tours de Babel: essais sur la traduction. Mauvezin, Trans-Europ Repress.

BICKERTON, D. (1975). Dynamics of a Creole System. Cambridge, U.K., Cambridge University Press.

CHINWEIZU, J. Onwuchekwa and M. IHECHUKWU (1980). Toward the Decolonization of African Literature: African Fiction and Poetry and their Critics. London, Routledge.

CATFORD, J. C. (1965). A Linguistic Theory of Translation. Oxford, Oxford University Press.

d'ALMEIDA, I. A. (1981). "Literary Translation: the Experience of Translating Chinua Achebe's Arrow of God into French," Babel XXVII (1), pp. 24-28.

FERGUSON, C. (1959). "Diglossia," Word 15, pp. 325-340.

GÉRARD, A. S., ed. (1986). European Language Writing in SubSaharan Africa, vol. I and II. Budapest, Akadémiai Kiado.

GILMAN, C. (1979). "Cameroonian Pidgin English; a neo-African Language," Readings in Creole Studies, I. Hancock ed. Ghent, EStory-Scientia, pp. 269-280.

HOLM, J. (1988). Pidgins and Creoles (vol. I): Theory and Structure. Cambridge University Press.

MUFWENE, S. (1988a). "English Pidgins: Form and Function," World Englishes VII(3), pp. 255-267.

(1988b). "Why study Pidgins and Creoles?" Journal of Pidgin and Creole Languages III(2), pp. 265-276. 
NIDA, E. (1976). "A Framework for the Analysis and Evaluation of Theories of Translation," Translation: Applications and Research, R. W. Brislin ed. New York, Gardner, pp. 47-91.

OBIECHINA, E. N. (1975). Culture, Tradition and Society in the West African Novel. Cambridge, U.K., Cambridge University Press.

OYONO, F. (1956). Une vie de boy. Paris, Éditions Julliard.

(1966). Houseboy. Trans. by J. Reed. London, Heinemann.

SCHNEIDER, G. D. (1966). West African Pidgin English. Ph.D. Dissertation. Athens, Ohio.

SOYINKA, W. (1981). Aké. London, Minerva.

TODD, L. (1982). Varieties of English Around the World: Cameroon. Heidelberg, Julius Groos Verlag.

(1984). Modern Englishes: Pidgins and Creoles. Oxford, Blackwell.

WALD, P., J. Chesny, M.-A. Hily and P. Poutignant, eds. (1973). Continuité et discontinuité sociolinguistiques: Hypothèses pour une recherche en Afrique noire. Nice, IDERIC, Université de Nice.

\footnotetext{
ABSTRACT:On Translating Pidgins and Creoles in African Literature - This paper deals with some of the problems of translating pidgins and creoles in African literature. It begins with an overview of the origins and parallel evolution of the French-based and English-based pidgins spoken in West Africa, throwing light on their status, history, and use in African literature. After a brief sociolinguistic analysis of the two hybrid languages, the paper discusses the difficulty of translating them, by carrying out a thorough analysis of translated examples and suggesting more appropriate solutions where necessary. The paper concludes by highlighting the reasons for the translation difficulties which are not only linguistic but also historical and ideological.
} 
RÉSUMÉ: De la traduction des pidgins et des créoles dans la littérature africaine - Cet article présente certains problèmes posés par la traduction des pidgins et des créoles dans la littérature africaine. L'introduction est un bref survol des origines et de l'évolution parallèle des pidgins à base lexicale anglaise et française parlés en Afrique de l'ouest, leur statut, leur histoire et leur usage dans la littérature africaine. Après un tour d'horizon des aspects sociolinguistiques de ces langues hybrides, l'auteur procède à une analyse des difficultés que pose leur traduction, et effectue une analyse approfondie de quelques traductions. Des versions plus adéquates sont proposées au besoin. En conclusion, sont mises en évidence les raisons de ces difficultés de nature non seulement linguistique mais historique et idéologique. 